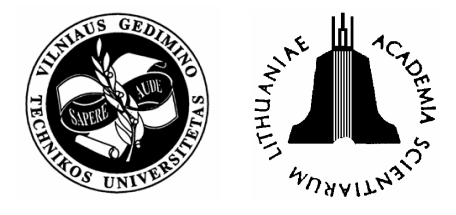

\title{
TRAINING NEEDS IN CONSTRUCTION PROJECT MANAGEMENT: A SURVEY OF 4 COUNTRIES OF THE EU
}

\author{
José Manuel Cardoso Teixeira ${ }^{1}$, Andrzej Minasowicz ${ }^{2}$, Edmundas Kazimieras Zavadskas ${ }^{3}$, \\ Leonas Ustinovichius ${ }^{3}$, Darius Migilinskas ${ }^{3}$, Eugenio Pellicer Armiñana ${ }^{4}$, \\ Pawel Olaf Nowak ${ }^{5}$, Mieczysław Grabiec ${ }^{6}$ \\ ${ }^{1}$ Dept of Civil Engineering University of Minho, Azurem, Guimaraes 4800, Portugal. \\ E-mail: jct@civil.uminho.pt \\ ${ }^{2}$ Warsaw University of Technology, Armii Ludowej 16, Warsaw 00-637, Poland. \\ E-mail: a.minasowicz@il.pw.edu.pl \\ ${ }^{3}$ Vilnius Gediminas Technical University, Sauletekio al. 11, LT-10223 Vilnius, Lithuania. \\ E-mail:Edmundas.Zavadskas@adm.vtu.lt; leonasu@st.vtu.lt; dariusmg@mail.lt \\ ${ }^{4}$ Polytechnic University of Valencia, Camino de Vera, Valencia s/n 46022, Spain. \\ E-mail: pellicer@cst.upv.es \\ ${ }^{5}$ Polish-British Construction Partnership, Wspólna 41/24, Warsaw 00-519, Poland. \\ E-mail: pbcp@pbcp.com.pl \\ ${ }^{6}$ Polish Association of Consulting Engineers and Experts, Piekatkiewicza 7, Warsaw 00-710, Poland. \\ E-mail: sidir_wwa@poczta.onet.pl \\ Received 08 Dec 2005; accepted 13 May 2006
}

\begin{abstract}
Knowledge on construction project management is a key issue in today's construction industry across Europe. This applies to the whole range of project participants from inception to conclusion of construction undertakings thereby involving professionals focusing in distinct perspectives yet working for a common goal. Several countries in Europe, with special relevance to the UK, have developed substantial knowledge in this topic through academic courses, professional training and experience of practitioners. Other countries have not achieved this stage but the need to prepare professionals to work in the open European market is impelling efforts for convergence in this matter. This article reports a survey on professional training needs in four European countries presently partnering in a Leonardo da Vinci project on management of construction infrastructure projects. The survey was carried by a questionnaire administered to a set of organisations of the construction cluster of the four countries involved. Results were used for defining 6 areas of interest for CPD courses which are presently being developed in the scope of the project.
\end{abstract}

Keywords: construction, project management, knowledge, training.

\section{Introduction}

The proposal to create in Poland the system of qualification certification of the managerial construction personnel and accreditation of the studies with the participation of employers has been prepared under the scheme of LdV Didactical project. Project partners: Dept of Construction Engineering and Management at Warsaw University of Technology (the Promoter, PL), Polish British Construction Partnership Ltd (PL), Construction Management Education Foundation (PL), European Construction Ventures Ltd (UK) and University of Minho (PT)) assumed that such a system could ensure the full clarity and recognition of the profession qualifications in construction similarly to other systems used in the EU. This was the reason to adopt as a content-related basis of this comparison the structure model of knowledge in the area of "management and engineering production in construction", presented in the report [1]. This model distin- guishes 5 different types of organisational units, which are present on the construction market and 5 different staff qualification profiles [2].

A discussion on problems related to research on the organisation, management, economics and technology in the Polish construction industry may be found elsewhere [3]. Scientific and, more specifically, academic circles are characterised and alarming phenomena that accompany practicing the issues of organisation and management in construction engineering are discussed: an increase of the number of employees with an economic education, phenomena related to finance, staff feminisation and fluctuations among other things. Trends observed in research and changes in the subject matter of interest to participants at scientific conferences are pointed out. Publication activity, dissertations and international cooperation are discussed. Non-serial publications of the last three years are listed. The analysis is based on a questionnaire circulated by the Construction Management Section of 
the Civil Engineering Committee of the Polish Academy of Science, the members of which are the authors of this article. The questionnaire covered a period of ten years. Furthermore, proceedings of conferences organised domestically under the patronage of the said Section as well as the effect of a trilateral international cooperation between Lithuania, Germany and Poland have been used.

Some attention is given to professional training in construction management in Lithuania, references to this subject may be found in [4-16]. Articles [4-5] present the achievements of Prof E. K. Zavadskas and Prof A. Kaklauskas in this field in 1997-2000. These authors analysed and suggested changes in the study process; they are mostly connected with the development and implementation of two post-graduate distance (Internet) study programmes of the Dept of Construction Technology and Management of the VGTU. A paper [6] reviews development, theoretical and practical experience of distance learning under two Master programmes in the Dept of Construction Economics and Property Management at the VGTU are presented. These programmes were among the first developed in Central and Eastern Europe.

The paper also analyses the results of a questionnaire issued to former and current students, mostly comprising staff from the real estate sector and construction companies. Conclusions emphasise the problems related to the learning process, social, economical, technological, and ethical issues and the integration of trained professionals into the market.

What concerns training, modern methods are now widely used. Based on the analysis of existing computer learning, neural networks, information, expert and decision-support systems, the following e-learning was developed by authors [9], including the following topics: construction, real estate, facilities management, international trade, ethics, innovation, sustainable development, building refurbishment etc. Application of the above multiple criteria computer learning systems developed by authors helps one to determine the strength and weakness of the analysed alternatives and their constituent parts. Calculations were made to find out by what degree one version is better than another one and why. Landmarks are set for an increase in the efficiency of versions etc. In the article [10] a case study method, which is amply used at Harvard Business School (USA) and also at European Business Schools characterised by top ratings, has been analysed. The case study method used as a management teaching tool for students and executives accomplishes and enhances conventional methods of teaching, such as lecturing, assigning practical tasks, reading of specialty literature etc. Nevertheless, despite the popularity of case study methods among prestigious Business Schools, various approaches to definition of a proper one for the teaching process case could be found, also different emphasises on process of application of this teaching method have been put.

After countries became the part of the EU, it is important to estimate results of integration effects in social, economic and other areas. One of underlying areas is workers' health and safety [7]. Analysis of data on acci- dents in construction companies shows that their main reasons are non-compliance of standard acts, wrongly organised work, the absence of security measures, poorly organised work place, insufficient training of workers [8].

This article describes the results of a survey conducted in four European countries on the recognition of needs of professional training in management of construction projects, in the scope of a Leonardo da Vinci project entitled "Recognition of needs and creation of professional training in the area of management of infrastructure construction projects (Leonardo da Vinci project reference $\mathrm{PL} / 04 / \mathrm{B} / \mathrm{P} / \mathrm{PP} /-174$ 417). Partners involved in the project were as follows:

- UMINHO - University of Minho, Portugal

- WUT - Department of Construction Engineering and Management at Warsaw University of Technology, Poland

- $\quad$ PBCP - Polish-British Construction Partnership, Poland

- $\quad$ PUV - Polytechnic University of Valencia, Spain

- VGTU - Vilnius Gediminas Technical University, Lithuania

- $\quad$ SIDIR - Polish Association of Consulting Engineers and Experts, Poland

According to the project aims, results will be used for helping the development of a set of future Continuous Professional Development (CPD) courses in the area of infrastructure projects management.

\section{Training needs for construction project management}

The identification, knowledge, assessment and maintenance of project management competencies are fundamental to the performance of contemporary engineering organisations [17] presently demanding management knowledge coupled with traditional skills from their staff [18]. Actually, knowledge and skills in the field of organisation and management have been widely recognised as a board category of knowledge that engineers will need in their future professional lives [19, 20]. Concern for project management competence has led to the development of standards for project management knowledge and practice that are used for assessment, development and certification [21]. Accreditation bodies for project management have long defined the main areas of knowledge required for certification [22-24] which basically concentrate on the technical requirements deemed essential for the project management practice. Accordingly, academic programmes in project management from the leading European learning institutions aim at covering a significant proportion of the accreditation demands.

Nevertheless, a survey of the partner countries' Higher Education Institutions revealed that little attention is devoted to construction project management learning in academic courses, despite the demand for continuous professional development in this area. Most of the academic learning is concentrated in traditional civil engineering courses that fail to efficiently address the most relevant aspects of the project management profession in the construction environment. Moreover, graduation in 
civil engineering mostly covers a variety of design oriented areas, leaving little room for management topics which are essential for effectively conducting construction projects [25]. It may be concluded that civil engineering curricula pay less attention to the management topics than they should, taking into account the current professional demands in this field [26], thus justifying the need for increasining the management focus in the civil engineering curriculum [20].

It has been widely recognised that project managers nowadays find themselves confronted by issues and undertaking additional roles that have traditionally not been part of their responsibility [27]. Modern project management practice therefore demands other management knowledge that exceeds the aspects of traditional civil engineering areas. Higher education institutions surveyed in the four countries involved in this project are now facing the problem on how to enlarge project management topics in their civil engineering curricula and on how to offer new learning opportunities to the construction industry knowledge demands.

However, the typically stuffed civil engineering curricula does not allow for an easy solution of this problem. Pellicer et al (2003) [28] identified two alternative solutions for a similar problem: either through a change of syllabus enforcing the required expertise, or by inserting relevant topics in courses pertaining to the current syllabuses. But offering elective courses in selected topics of construction project management may be efficient in some curricula whereas incorporating similar topics in other courses may result impracticable in other curricula. Beyond academic traditional curricula, CPD has been receiving increasing attention in recent decades, as construction professionals feel the need for expanding knowledge acquired in academia and are required to keep themselves up-to-date with new developments in the rapidly changing built environment [29].

In recent years, it has been claimed that knowledge actually required for project management practice is much wider than that learned in academic courses. A survey to 170 project managers from the UK construction industry showed that formal training and job experience mostly contribute for delivering project management competence [27]. Professional competency in project management is actually attained by the combination of knowledge acquired during training and skills developed through experience and the application of the acquired knowledge [27]. Main reasons for this are the rapidly changing construction environment, the continuous demands of the project management profession and the lack of coverage of relevant management issues in current academic curricula [27].

\section{Inquiring the construction cluster}

Background. The analysis of professional needs in construction project management is a key factor for defining relevant training programmes either for undergraduate, graduate and continuous professional development. The recognition of the lack of knowledge on this topic in partner countries involved in the project led to the decision of launching a similar inquiry in each country with the following aims:

- To identify the most relevant management areas in construction.

- To collect information on courses provided by organisations inquired in the area of construction project management.

To estimate the probable number of attendants for training courses to be promoted on a set of preferred subjects set up from the results of the inquiry.

Experience gained from similar inquiries conducted in Portugal and in Poland was used in order to best structure this inquiry. Previous inquiries took place in the scope of a former Leonardo da Vinci project adopted the form of a mailed questionnaire to a set of selected organisational units within the construction cluster in both countries [30-31]. A construction organisational unit was defined as a separate entity, which:

- operates to achieve the specific aims, to fulfil the particular functions in favour of other units, which are the subjects of its action,

- $\quad$ is described by its own structure, which determines the range of abilities in fulfilling the specific functions,

- $\quad$ is described by a suitable form of property law,

- $\quad$ has its value and price,

- co-operates with other "organisational units", under the regulations of the market supply and demand law and is based on the contractual relationships,

- $\quad$ is subjected to the independent system of regulations.

Actually, the use of postal questionnaires is an effective research technique for measuring the research variables on the basis of the respondents' perception of their work environment and their own conduct [32] and has been widely used by education researchers to help inquiring construction professionals on learning needs and professional practice trends [29].

Research approach. According to aims and in view of the organisation structure reckoned, a questionnaire was developed and used in a mailed inquiry to a set of previously selected organisations operating in each partner country. The questionnaire was structured in order to obtain information on organisations inquired. The following aspects are covered by the questionnaire:

- Organisation type:

- Contractor;

- Consultant / Project Manager;

- Governmental Organisation/Local Authorities;

- Private Investor / Client / Developer;

- Professional Associations related to Construction;

- Other.

- Number of staff: managers and engineers.

Relevant management areas in construction had been identified in former research [30] as follows:

- Project Conception Development / Feasibility,

- Planning and Scheduling,

- Risk Management,

- Corporate Marketing,

- Project Cost Estimation and Cost Management, 
- Quality Management,

- Procurement and Tendering Procedures,

- Contract Conditions,

- Joint Ventures / Partnering (PPP),

- Health and Safety Management,

- Handing Over / Guarantee Period,

- Environmental Management,

- Other.

About the information on courses already provided, the questionnaire focused on:

- type of course (internal, external, distance learning),

- number of participants in each course,

- $\quad$ subject of the course.

On the interest in training courses in the area of management in construction, the questionnaire addressed the most relevant type of the course, whether internal, external or distance learning.

\section{Results and discussion}

Type of organisations inquired. Table 1 and Fig 1 present information about respondent organisations. Table 1 shows the number of organisations inquired and their types in each country surveyed. A reasonable distribution among distinct types of organisations may be perceived. Contractors were inquired in larger number than others thus reflecting similar production structures in each country. Approximately 300 organisations participated in the survey, half of those are contractors.

Fig 1 graphically depicts the same information of Table 1, but allows for an easy comparison among the number of organisations involved in the study from each type.

Most relevant management areas. Table 2 illustrates the opinions on the most relevant management areas selected by each type of organisation in the four countries surveyed. In each country, respondents were asked to select the top five areas in their current activity. Moreover, two countries used the survey to inquire on other related topics. The questionnaire used in Spain further asked for the five most important needs in professional training and the questionnaire used in Lithuania aimed at establishing the connection between areas selected and the main working activity of respondents.

Data collected show a reasonable convergence of the respondents in the four most selected areas of interest, irrespectively of the type of organisation inquired (shadow rows of Table 2). Obviously, answers from contractors weight much in the final results because they count for more than $50 \%$ of the organisations inquired and that was taken into account when deciding for which areas to concentrate on course development.

Moreover, data collected in each country also denotes similar concerns. Figures not shown in this article but available from [33] evidence that "Planning and Scheduling" and "Project Cost Estimation and Cost Management" were among the most selected areas in all countries; "Quality Management" was not among the most selected in Poland only; "Procurement and Tendering Procedures" was also one of the most relevant areas for all countries but one (Portugal).

Total figures summarised in the last column of Table 2 show that the selection of the above four areas is consistent with the choice of the majority of organisations inquired. Remarkably, this results from 1489 opinions collected in four surveyed countries.

Beyond the four areas identified above, it was decided to pick up two more areas for CPD course development. The following two in preference (see last column of Table 1), namely, "Project Conception/Development" and "Health and Safety Management" were selected. The first had a strong preference from Polish and Lithuanian professional associations [33], whereas the second was ranked five by contractors from all countries and was insistently elected by Portuguese and Spanish contractors, ranking three in preference in both countries. Fig 2 graphically summarises the contents of Table 2 for the six areas discussed.

Training provided. Figs 3 and 4 compare the percentage of organisations surveyed which have already provided training in construction management for their staff and the type of training selected. Except for Poland, more than half of the organisations inquired had already provided construction management training for their staff. External courses seem to have been preferred in all countries.

Table 1. Number and types of organisations inquired

\begin{tabular}{l|ccccc}
\hline Type of organisation & Poland & Portugal & Spain & Lithuania & TOTAL \\
\hline Contractor & 36 & 13 & 76 & 31 & 156 \\
Consultant / Project manager & 21 & 4 & 27 & 7 & 59 \\
Governmental organisation / Local authorities / Public & 11 & 5 & 11 & 2 & 29 \\
agencies & 6 & 7 & 13 & 3 & 29 \\
Private investor / client / developer & 1 & 0 & 0 & 3 & 4 \\
Professional associations related to construction & 6 & 1 & 8 & 1 & 16 \\
Other & $\mathbf{8 1}$ & $\mathbf{3 0}$ & $\mathbf{1 3 5}$ & $\mathbf{4 7}$ & $\mathbf{2 9 3}$ \\
\hline Total & & &
\end{tabular}


Table 2. Most relevant management areas

\begin{tabular}{|c|c|c|c|c|c|c|c|c|c|c|c|c|c|c|}
\hline $\begin{array}{l}\text { Management } \\
\text { areas }\end{array}$ & \multicolumn{2}{|c|}{ Contractors } & \multicolumn{2}{|c|}{$\begin{array}{l}\text { Consultants / } \\
\text { Project man- } \\
\text { agers }\end{array}$} & \multicolumn{2}{|c|}{$\begin{array}{c}\text { Governmental } \\
\text { organisation / } \\
\text { Local authorities }\end{array}$} & \multicolumn{2}{|c|}{$\begin{array}{c}\text { Private } \\
\text { investor / } \\
\text { Client / } \\
\text { developer }\end{array}$} & \multicolumn{2}{|c|}{$\begin{array}{l}\text { Professional } \\
\text { associations } \\
\text { related to } \\
\text { construction }\end{array}$} & \multicolumn{2}{|c|}{ Other } & \multicolumn{2}{|c|}{ TOTAL } \\
\hline feasibility & 58 & $7,26 \%$ & 32 & $10,53 \%$ & 14 & $10,14 \%$ & 17 & $11,49 \%$ & 4 & $21,05 \%$ & 6 & $7,41 \%$ & 131 & $8,80 \%$ \\
\hline $\begin{array}{l}\text { Planning and } \\
\text { scheduling }\end{array}$ & 122 & $15,27 \%$ & 38 & $12,50 \%$ & 17 & $12,32 \%$ & 18 & $12,16 \%$ & 2 & $10,53 \%$ & 13 & $16,05 \%$ & 210 & $14,10 \%$ \\
\hline $\begin{array}{l}\text { Risk management } \\
\text { Corporate market- } \\
\text { ing }\end{array}$ & $\begin{array}{l}55 \\
29\end{array}$ & $\begin{array}{l}6,88 \% \\
3,63 \%\end{array}$ & $\begin{array}{l}22 \\
16\end{array}$ & $\begin{array}{l}7,24 \% \\
5,26 \%\end{array}$ & 8 & $\begin{array}{l}5,80 \% \\
1,45 \%\end{array}$ & $\begin{array}{l}9 \\
5\end{array}$ & $\begin{array}{l}6,08 \% \\
3,38 \%\end{array}$ & 1 & $\begin{array}{l}5,26 \% \\
5,26 \%\end{array}$ & 5 & $\begin{array}{l}6,17 \% \\
3,70 \%\end{array}$ & $\begin{array}{l}100 \\
56\end{array}$ & $\begin{array}{l}6,72 \% \\
3,76 \%\end{array}$ \\
\hline $\begin{array}{l}\text { Project cost esti- } \\
\text { mation and cost } \\
\text { management } \\
\text { Quality manage- } \\
\text { ment } \\
\text { Procurement and } \\
\text { tendering proce- } \\
\text { dures }\end{array}$ & 115 & $11,01 \%$ & 37 & $\begin{array}{l}13,16 \% \\
12,17 \%\end{array}$ & 21 & $15,22 \%$ & 16 & $10,81 \%$ & 3 & $15,79 \%$ & 13 & $\begin{array}{l}16,05 \% \\
13,58 \%\end{array}$ & 215 & $\begin{array}{l}14,44 \% \\
11,15 \%\end{array}$ \\
\hline $\begin{array}{l}\text { Contract condi- } \\
\text { tions } \\
\text { Joint ventures / }\end{array}$ & 60 & $7,51 \%$ & 23 & $7,57 \%$ & 15 & $10,87 \%$ & 10 & $6,76 \%$ & 1 & $5,26 \%$ & 8 & $9,88 \%$ & 117 & $7,86 \%$ \\
\hline $\begin{array}{l}\text { partnering (PPP) } \\
\text { Health and safety } \\
\text { management }\end{array}$ & 26 & $3,25 \%$ & 8 & $2,63 \%$ & 9 & $6,52 \%$ & 6 & $4,05 \%$ & 1 & $5,26 \%$ & 0 & $0,00 \%$ & 50 & $3,36 \%$ \\
\hline $\begin{array}{l}\text { management } \\
\text { Handing over / } \\
\text { guarantee period }\end{array}$ & $\begin{array}{l}85 \\
37\end{array}$ & $\begin{array}{l}10,64 \% \\
4,63 \%\end{array}$ & $\begin{array}{l}19 \\
13\end{array}$ & $\begin{array}{l}6,25 \% \\
4,28 \%\end{array}$ & $\begin{array}{l}10 \\
6\end{array}$ & $\begin{array}{l}7,25 \% \\
4,35 \%\end{array}$ & $\begin{array}{l}11 \\
13\end{array}$ & $\begin{array}{l}7,43 \% \\
8,78 \%\end{array}$ & 1 & $5,26 \%$ & 8 & $9,88 \%$ & 134 & $9,00 \%$ \\
\hline $\begin{array}{l}\text { Environmental } \\
\text { management }\end{array}$ & 38 & $4,76 \%$ & 22 & $7,24 \%$ & 7 & $5,07 \%$ & 5 & $3,38 \%$ & 0 & $0,00 \%$ & 2 & $2,47 \%$ & 74 & $4,97 \%$ \\
\hline Other & 6 & $0,75 \%$ & 3 & $0,99 \%$ & 2 & $1,45 \%$ & 4 & $2,70 \%$ & 0 & $0,00 \%$ & 2 & $2,47 \%$ & 17 & $1,14 \%$ \\
\hline Total & 799 & $100 \%$ & 304 & $100 \%$ & 138 & $100 \%$ & 148 & $100 \%$ & 19 & $100 \%$ & 81 & $100 \%$ & 1489 & $100 \%$ \\
\hline
\end{tabular}

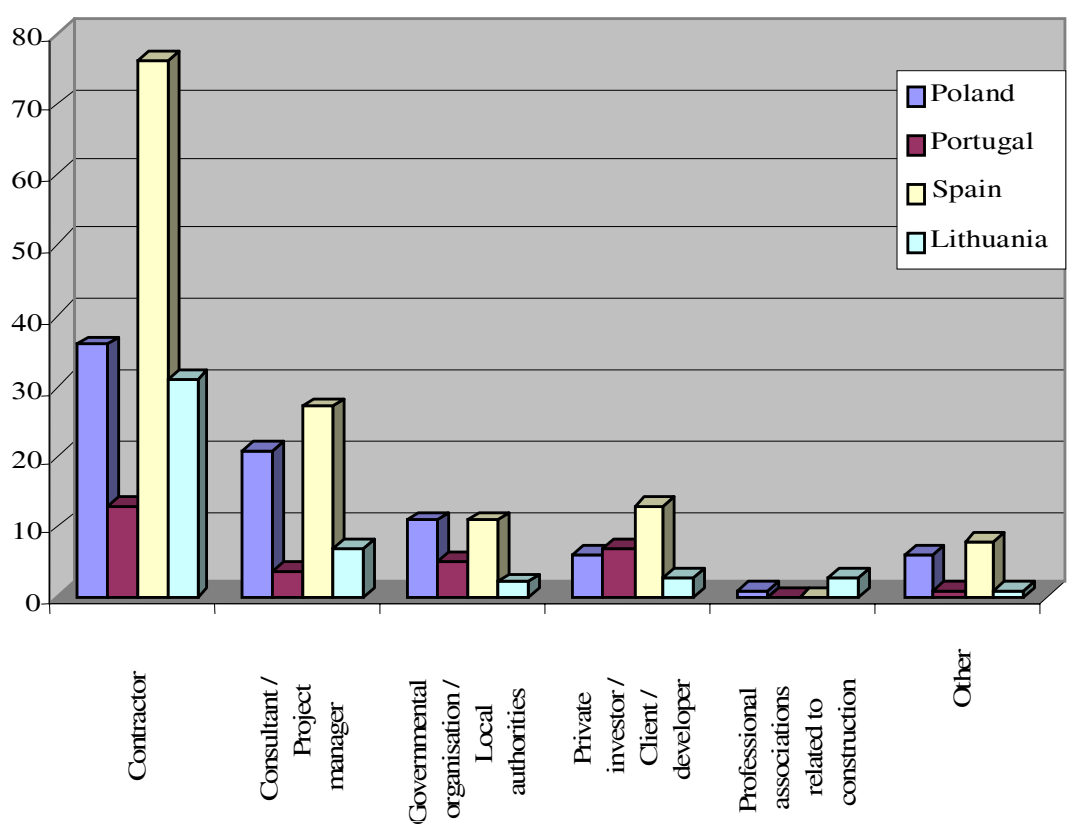

Fig 1. Weight of organisation types in the survey in four partner countries

Training preferred. Fig 5 shows that most organisations inquired prefer external courses. Internal course preference comes next for all countries except Spain where it appears that distance learning already made its way as an interesting means of training. However, it seems that organisations are happy with the type of train- ing in construction management they have been selecting for their staff (compare Figs 4, 5).

About the interest in future training, organisations inquired looked enthusiastic: over $85 \%$ in the 4 countries stated that they would be interested [33] and estimated a fairly high number of participants for forthcoming courses (Fig 6). 


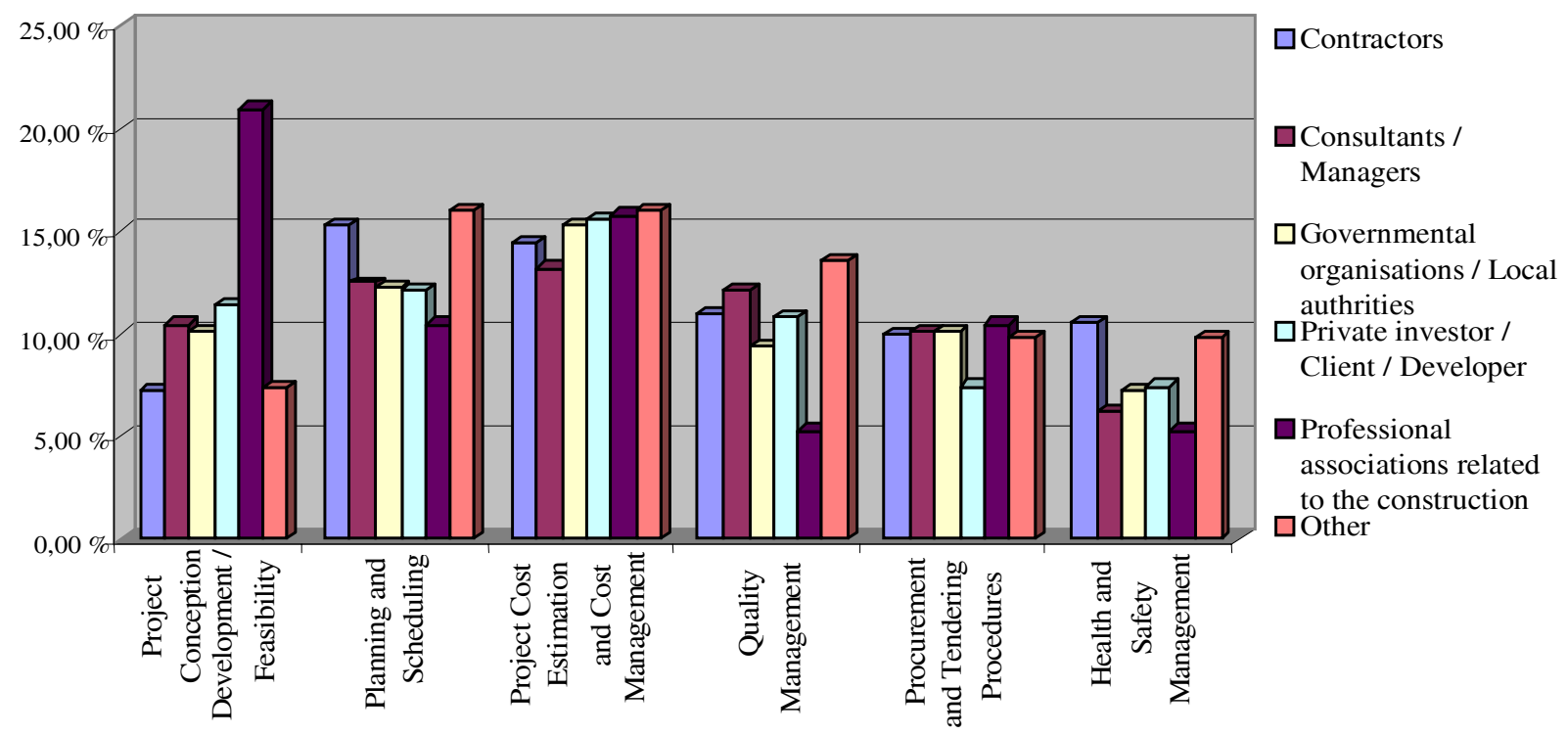

Fig 2. Organisation preference of relevant management areas

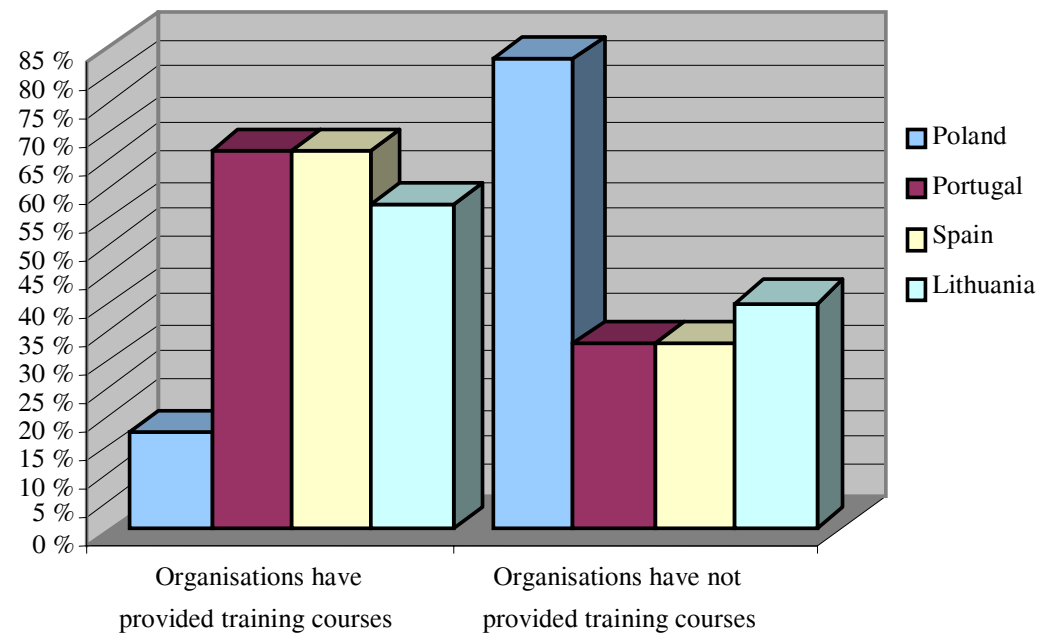

Fig 3. Training provided in construction management

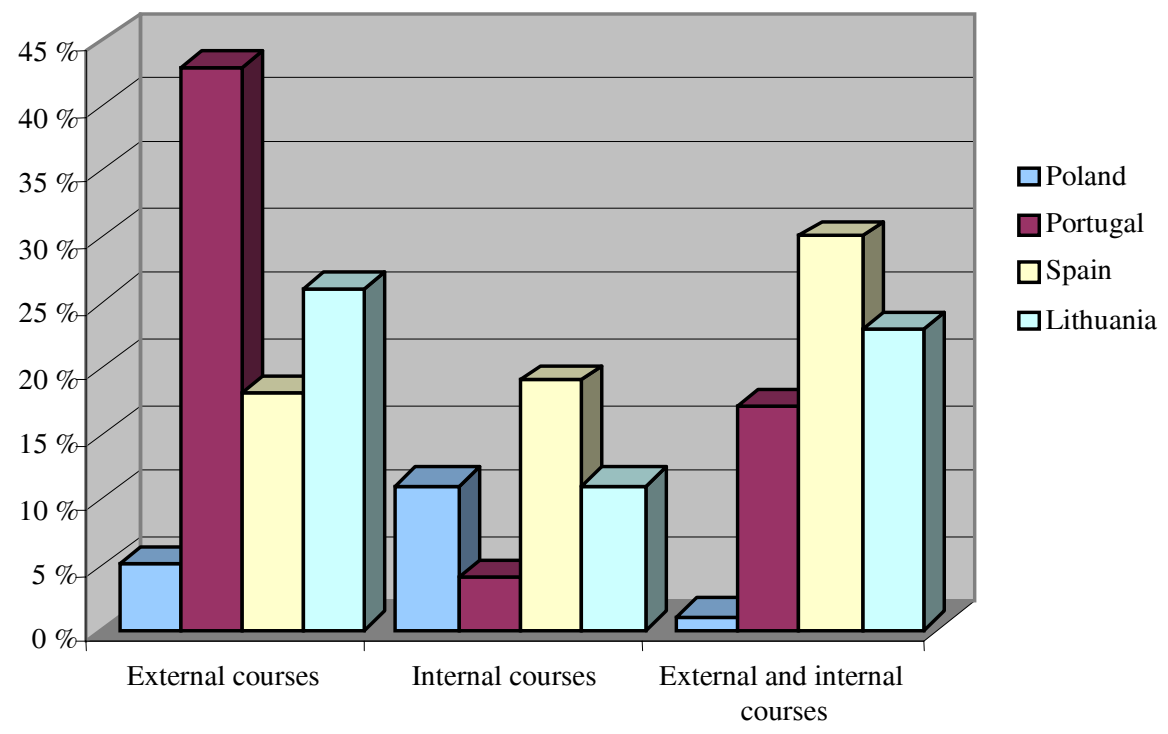

Fig 4. Type of training in construction management 


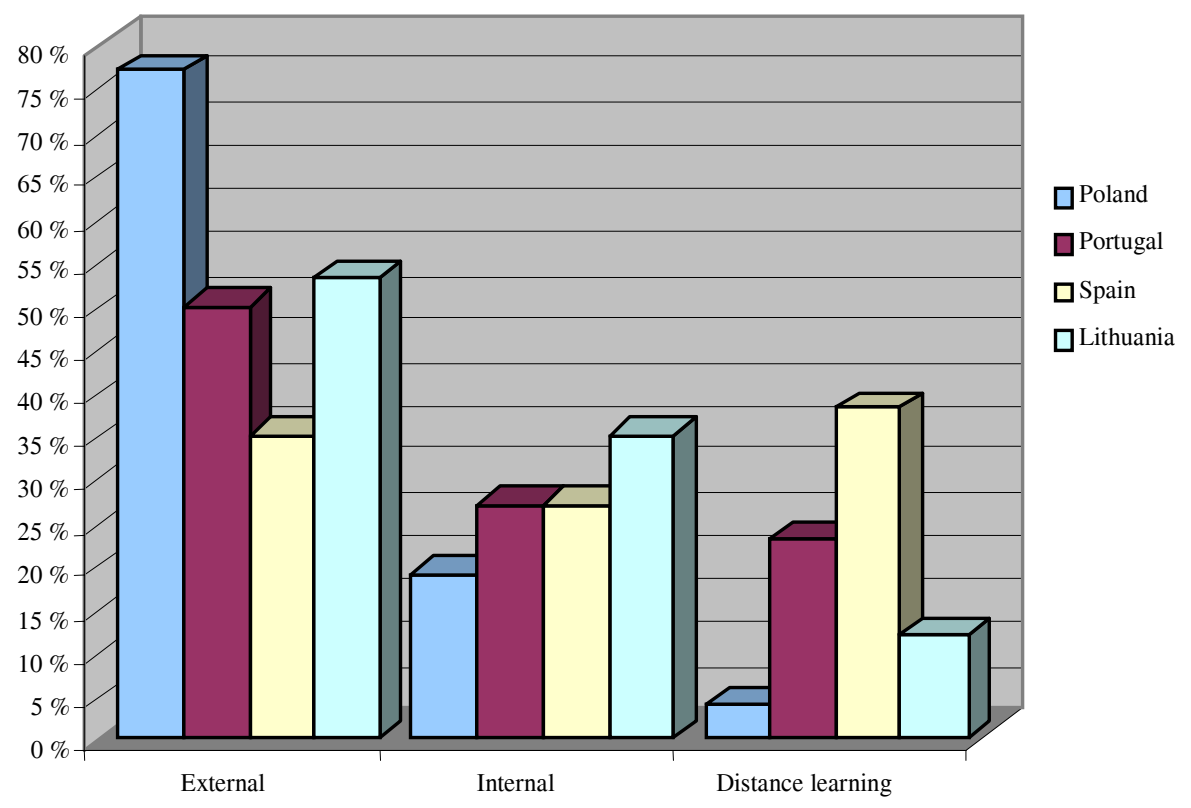

Fig 5. Preferred type of training

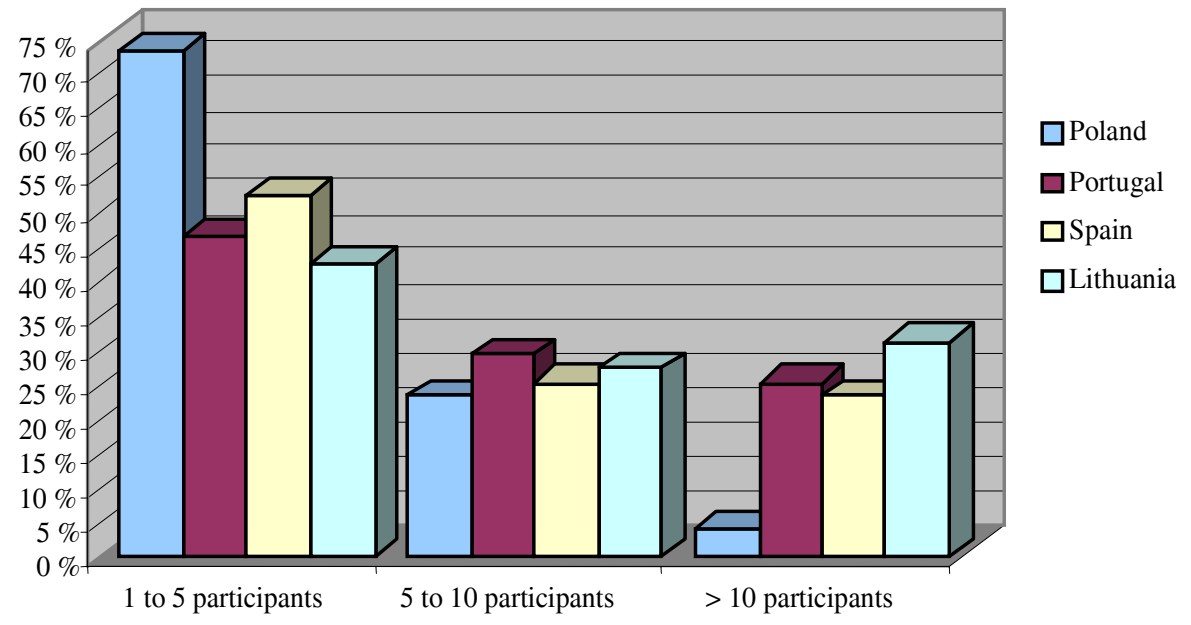

Fig 6. Estimate of the number of participants in forthcoming courses

\section{Conclusions}

The training needs of Portuguese, Polish, Spanish and Lithuanian construction engineers and managers were assessed through questionnaires sent to various organisations operating in the construction cluster of these countries. According to the results, the most relevant management areas selected were:

- Project conception development/feasibility;

- Planning and scheduling;

- Project cost estimation and cost management;

- Quality management;

- $\quad$ Procurement and tendering procedures;

- Health and safety management.

Furthermore, organisations inquired revealed a strong interest for training in the selected areas and predicted an encouraging number of participants for the forthcoming courses. Accordingly, CPD courses in the above areas of management of infrastructure construction projects are currently being developed in the scope of the project.

\section{References}

1. Final report. Development of new type of studies and courses in the field of management in construction for engineers according to the requirements of European Union, Warsaw, Manchester, Porto, 2002.

2. Minasowicz, A.; Nowak, P. Leonardo da Vinci projects enhancing construction manager's skills across European Union. Construction Information Quarterly, Vol 7, No 2, 2000, p. 397-414.

3. Kapliński, O.; Zavadskas, E. K. An overview of the problems related to research in construction engineering, management and economics in Poland. Journal of Civil Engineering and Management, Vol 8, No 4, 2002, p. 231239.

4. Kapliński, O.; Zavadskas, E. K. Expert systems for construction processes. Statyba (Civil Engineering), No 4. Vilnius: Technika, 1997, p. 49-61. 
5. Zavadskas, E. K.; Kaklauskas, A. Efficiency increase in research and studies while applying up-to-date information technologies. Statyba (Civil Engineering), Vol 6, No 6. Vilnius: Technika, 2000, p. 397-414.

6. Rimkuviene, S.; Lepkova, N. Analysis of experience and efficiency of distance learning Master's degree programme in construction economics and property management. Journal of Civil Engineering and Management, Vol 10, No 1, 2004, p. 51-60.

7. $\breve{S}$ ukys, R. Perspectives and problems of health and safety in construction. Journal of Civil Engineering and Management, Vol 10, Suppl 1, 2004, p. 51-55.

8. Vakrinienè, S.; Čyras, P.; Šukys, R. Traumata prevention resources optimization in construction. Journal of Civil Engineering and Management, Vol 10, Suppl 1, p. 57-63.

9. Ginevičius, R.; Zavadskas, E. K.; Kaklauskas, A. Efficiency increase of e-learning by applying on-line intelligence computer learning systems. Journal of Business Economics and Management, Vol 4, No 3, 2003, p. 203207.

10. Tvaronavičienè, M.; Ginevičius, R. Application of case teaching technique in educational process. Journal of Business Economics and Management, Vol 4, No 4, 2003, p. 217-221.

11. Saee, J. Internalisation strategy for education in the $21 \mathrm{st}$ century. Journal of Business Economics and Management, Vol 5, No 2, 2004, p. 77-84.

12. Zavadskas, E. K.; Kaklauskas, A.; Lepkova, N. Multiple criteria analysis of facilities management alternatives. Property Management, Vol 6, No 1, 2002, p. 31-39.

13. Čyras, P.; Jakutis, A.; V. Rutkauskas, A.; Šukys, R. The costs of the execution of the EC directive about safe labour. Technological and Economic Development of Economy, Vol 9, No 1, 2003, p. 60-66.

14. Melnikas, B. The integration of international studies as a part of business environment. Business: Theory and Practice, Vol 2, No 1, 2002, p. 31-40.

15. Stankevičius, P. The attitude of Lithuanian students towards work, business and employment possibilities. Business: Theory and Practice, Vol 4, No 2, 2004, p. 59-64.

16. Tvaronavičienè, M. Case study as a tool of managers' education. Business: Theory and Practice, Vol 2, No 2, 2002, p. 118-122.

17. Trejo, D.; Patel, S.; Andersen, S.; Cervantes E. Framework for competency and capability assessment for resource allocation. Journal of Management in Engineering, Vol 18, No 1, 2003, p. 44-49.

18. Edum-Fotwe, F. T.; McCaffer, R. Developing project management competency: perspectives from the construction industry. International Journal of Project Management, Vol 18, 2000, p. 111-124.

19. De Graaff, E.; Ravesteinjn, W. Training complete engineers: global enterprise and engineering education. Euro- pean Journal of Engineering Education, Vol 26, No 4, 2001, p. 419-427.

20. Chinowsky, P. S. Integrating management breadth in civil engineering education. Journal of Professional Issues in Engineering Education and Practice, Vol 128, No 3, 2002, p. 138-143.

21. Crawford, L. Senior management perceptions of project management competence. International Journal of Project Management, Vol 23, 2005, p. 7-16.

22. Duncan, W. R. A guide to the project management body of knowledge. Project Management Institute Standards Committee, Upper Darby PA: PMI, 1996.

23. Association of project managers. Body of knowledge. High Wycombe: APC, 1995.

24. Caupin, G.; Knopfel, H.; Morris, P.; Motzel, E.; Pannenbacker, O. ICB: IPMA competence Baseline. Germany: International Project Management Association, 1999.

25. Teixeira, J. Construction site environmental impact in civil engineering education. European Journal of Engineering Education, Vol 30, No 1, 2005, p. 51-58.

26. Christodoulou, S. Educating civil engineering professionals of tomorrow. Journal of Professional Issues in Engineering Education and Practice, Vol 131, No 2, 2004, p. $158-159$.

27. Edum-Fotwe, F. T.; McCaffer, R. Developing project management competency: perspectives from the construction industry. International Journal of Project Management, Vol 18, 2000, p. 111-124.

28. Pellicer, E.; Seron, J. B.; Catalá, J.; Leopoldo, J. J. Proposal of a new academic frame for the civil engineering education in construction safety and health. In: International Conference on Engineering Education, Valência, Spain, 2003.

29. Chan, E. W. C.; Chan A. T. S. Development of professional system in the construction industry of China. Journal of Construction Research, Vol 3, No 2, 2002, p. 271284.

30. WP III Report on Portuguese inquiry and focus group. Improvement of the linguistic skills in the English language of Polish and Portuguese construction managers and engineers, Leonardo da Vinci project, number PL/01/B/F/LA/140310, 2004.

31. WP IV Portuguese report. Model of professional qualification structure and new methods of promotion, certification and mutual recognition of managerial skills in the construction industry according to the requirements of the EU, Leonardo da Vinci project, number PL/02/B/F/PP/140 029, 2004.

32. Mintzberg, H. The nature of managerial work, Harper and Row, New York, 1973.

33. WP II Report. Recognition of needs and creation of professional training in the area of management of infrastructure construction projects, Leonardo da Vinci project, number PL/04/B/P/PP/-174 417, 2005. 


\section{MOKYMO KURSU POREIKIAI VALDANT STATYBOS PROJEKTUS: KETURIU ES VALSTYBIU APŽVALGA}

\section{J. M. Cardoso Teixeira, A. Minasowicz, E. K. Zavadskas, L. Ustinovichius, D. Migilinskas, E. Pellicer Armiñana, P. O.Nowak, M. Grabiec}

S antrauka

Statybos projektų valdymo principų mokymas šiuo metu yra vienas iš pagrindinių tikslų visos Europos statybos pramoneje. Tai susiję su visais projekto dalyviais nuo pradžios iki statybos pabaigos. Taip i šią veiklą ịtraukiami ịvairūs specialistai, kurie siekia bendrų tikslų, bet dirba skirtingose statybos srityse.

Kelios Europos valstybės, ypač Didžioji Britanija, kursų metu esmingai moke ịvairaus lygio specialistus. Kitos šalys nepasieke šios stadijos, bet poreikiai parengti profesionalus dirbti atviroje Europos rinkoje suaktyvino pastangas ši klausimą spręsti. Šiame straipsnyje pateikta profesionalaus mokymo kursų poreikių analizès ataskaita keturiose Europos šalyse, kurios dalyvauja Leonardo da Vinci projekte, skirtame statybos infrastruktūros projektui valdyti. Analizè atlikta apklausos būdu. Apklausos anketos buvo nusiųstos keturių šalių statybos organizacijoms. Apklausos rezultatai naudojami nustatant šešis kursų dalykus, vykdomus šiame projekte.

Reikšminiai žodžiai: statyba, projektų valdymas, žinios, mokymas.

José Manuel CARDOSO TEIXEIRA. Doctor, Associate Professor of University of Minho, Portugal. PhD in Construction Management by Loughborough University of Technology (UK). In the scope of the lecturing activities he has been responsible for various courses in training programmes at the University of Minho, Portugal. His scientific activities included the participation in research projects, the supervision of final year student projects, the supervision of scientific projects, the participation in jury of academic exams. Author of many articles, papers and books.

Andrzej MINASOWICZ. PhD Engineer, Vice Director of Dept of Construction Engineering and Management, Warsaw University of Technology, Faculty of Civil Engineering. His membership in Professional Societies: Member of Association of Consulting Engineers and Experts (SIDIR), Fellow of Institution of Civil Engineering (ICE), Member of the Association for Total Cost Management, Member of American Association of Cost Estimators (AACE), Member of Science Association of Construction Process Engineering, Fellow of Chartered Institute of Building (CIOB). He is promoter of many Leonardo da Vinci projects, author of many articles and papers in Polish and foreign languages.

Edmundas Kazimieras ZAVADSKAS. Doctor Habil, Professor, Dr honoris causa of Poznan University of Technology, Vice Rector of Vilnius Gediminas Technical University (Lithuania). Member of Lithuanian Academy of Sciences, President of Lithuanian Operational Research Societies, President of Alliance of Experts of projects and buildings of Lithuania. Editor-in-Chief of the "Journal of Civil Engineering and Management", "Technological and Economic Development of Economy"; Editor of the "International Journal of Strategic Property Management". The author of more than 300 scientific papers, 11 books. Research activities: building technology and management, decision-making theory, automation in design, expert systems.

Leonas USTINOVICHIUS. Doctor Habil, Professor, Chairman of laboratory of construction technology and management of Vilnius Gediminas Technical University, Lithuania. Associate Academician of International Informatisation Academy, Deputy Editor-in-Chief of the Journal "Technological and Economic Development of Economy", participates in Leonardo da Vinci programmes. Author of more than 130 publications and 3 monographs. Research interests and activities: multiple attribute valuation and automated programming of technological solutions in construction and investment project efficiency, decision support systems building technology and management, decision-making theory, automation in design, expert systems.

Darius MIGILINSKAS. Master of Civil Engineering, PhD student in Dept of Construction Technology and Management, Vilnius Gediminas Technical University (Lithuania). Bachelor (2001) and Master (2003) degrees in Vilnius Gediminas Technical University, a participant of Leonardo da Vinci programmes. More than 10 publications in scientific papers. Research interests and activities: building technology and construction work management, decision-making and normalisation methods, game theory adaptation in construction, computer-aided systems in design and construction evaluation.

Eugenio PELLICER ARMiÑANA. PhD Doctor in Civil Engineering, Associate Professor of departamento de la construccion proyectos de ingenieria civil universidad politecnica de Valencia, Spain. Author of 39 papers and chapters of books, 6 books.

Pawel Olaf NOWAK. PhD Engineer in Dept of Construction Engineering and Management, Warsaw University of Technology, Faculty of Civil Engineering. His membership in Professional Societies: Fellow of Chartered Institute of Building (CIOB), Member of Association of Consulting Engineers and Experts (SIDIR). Author of many articles and papers in Polish and foreign languages.

Mieczysław GRABIEC. Graduate of AGH University of Science and Technology in Cracow. President of the board of SIDiR (Stowarzyszenie Inżynierów Doradców i Rzeczoznawców) since 1998. Member of international professional organisations such as International Federation of Consulting Engineering (Fédération Internationale des Ingěnieurs Conseils - FIDIC) since 1991. As a licensed Arbitrator and Expert in international contract conditions FIDIC, he held a role of Engineer Resident for many contracts in Poland and abroad. Rich professional experience he uses in consultancy services for World Bank, National Fund for Evironment Protection etc. Also a trainer and speaker on many courses and seminars dedicated to FIDIC issues in Polish and the international law. As a manager of many European funded projects, he participated in preparation of tender documentation for the building of University of Warsaw Library, participated in the EU funded Leonardo da Vinci project. 